University of Nebraska - Lincoln

DigitalCommons@University of Nebraska - Lincoln

To Improve the Academy

Professional and Organizational Development Network in Higher Education

1994

Metaphors of Teaching: Uncovering Hidden Instructional Values

Darlene Hoffman

Follow this and additional works at: https://digitalcommons.unl.edu/podimproveacad

Part of the Higher Education Administration Commons

Hoffman, Darlene, "Metaphors of Teaching: Uncovering Hidden Instructional Values" (1994). To Improve the Academy. 309.

https://digitalcommons.unl.edu/podimproveacad/309

This Article is brought to you for free and open access by the Professional and Organizational Development Network in Higher Education at DigitalCommons@University of Nebraska - Lincoln. It has been accepted for inclusion in To Improve the Academy by an authorized administrator of DigitalCommons@University of Nebraska - Lincoln. 


\section{Metaphors of Teaching: Uncovering Hidden Instructional Values}

\section{Darlene Hoffman}

Millikin University

This paper describes how metaphors of teaching can be used to assist faculty in understanding the assumptions that underlie their teaching behaviors. A problem-based and a values-based model are described. In the problem-based model, there is no assumption of a metaphor. In the values-based model, the metaphors are seen as filters through which all efforts to improve teaching must pass. By understanding these values agendas, faculty consultants will have more success in facilitating teaching effectiveness.

What exactly are instructional values? How do they relate to faculty consulting? In the first session of a nine-week teaching-effectiveness workshop, faculty examined their values by completing the following task:

Selecting the color of crayon which appeals to you, use words, images, or symbols to draw a picture which represents your conception of teaching. Think of yourself as teaching at your best.

After a few minutes of drawing time, the faculty shared their drawings. They enthusiastically explained their metaphors to the group, using group feedback to refine and expand their ideas.

Next, faculty worked in dyads to discuss the following questions: 
What values do you see reflected in your metaphors? Think about the way you teach. How does your teaching reflect your values? What examples can you give that illustrate your metaphor in action?

The metaphor activity resulted in immediate and enthusiastic faculty involvement. Additionally, it provided an integrative focus for discussions throughout the nine-week seminar. Most importantly, however, it revealed instructional values that are a hidden agenda of faculty development activities.

Instructional values affect the way faculty teach, what they expect of their students, and what they expect of themselves as teachers. In fact, most instructional decision making involves values-based decisions. As Raths, Harmin, and Simon (1966), Simon, Kirschenbaum, and Howe (1972), Rokeach (1968), and Holt (1969) have pointed out, values and teaching are inextricably linked. Thus, teachers who want to improve their teaching effectiveness must be assisted in recognizing their own instructional values. The seminar, which was conducted for the first time at Millikin University, revealed that faculty members' values had a direct impact on how they responded to the ideas and information presented in the seminar.

\section{Two Models of Faculty Consulting}

\section{A Problem-Based Model}

The teaching-effectiveness seminar began with a model that is quite common among faculty consultants, one much like those described by Shackelford (1993) and Evans and Chauvin (1993). Developing a program for teaching improvement typically begins with understanding faculty concerns and perceived needs or problems and then designing appropriate instructional activities.

Figure 1 shows this Problem-Based Model of faculty consulting. It assumes that a faculty consultant brings to the consulting process a supportive attitude as well as skills and strategies to share with faculty, either individually or in workshops or seminars. Faculty members also bring to the consulting relationship skills and strategies of teaching, as well as their own styles of teaching. Normally, then, the faculty members describe a problem with which they would like to have 
assistance. The consultant and the faculty members then interact, bringing their knowledge of skills and strategies together to solve the problem.

A teaching effectiveness seminar tailored to the specific needs and interests of faculty can begin with a problem-based model. In the seminar at Millikin University, the faculty consultant asked all participants to complete a survey concerning their level of satisfaction with their skills in 14 different teaching areas (see Appendix A). Prior to the first session of the seminar, participants filled out a questionnaire describing what they hoped to accomplish in the workshop. The syllabus for the seminar, emphasizing the stated interests of the faculty was then developed. Predictably, the participants in this seminar expressed a desire to improve their skills in motivating students, increasing involvement of students in their own learning, learning new teaching strategies, facilitating cooperative learning, and developing more interesting lectures. The stated agendas of the faculty were similar to those identified by Kerwin (1987) as behaviors faculty wanted to develop. Also, the skills with which the faculty were most

\section{FIGURE 1: Problem Based Model}

\section{The Process of Faculty Consulting}

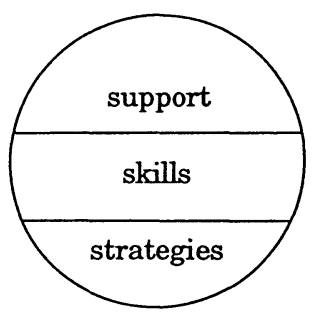

Consultant

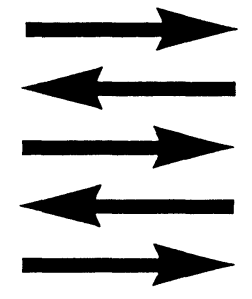

\begin{tabular}{|c|}
\hline $\mathrm{P}$ \\
$\mathrm{R}$ \\
$\mathrm{O}$ \\
$\mathrm{B}$ \\
$\mathrm{L}$ \\
$\mathrm{E}$ \\
$\mathrm{M}$ \\
\hline $\mathrm{A}$ \\
$\mathrm{G}$ \\
$\mathrm{E}$ \\
$\mathrm{N}$ \\
$\mathrm{D}$ \\
$\mathrm{A}$ \\
\hline
\end{tabular}

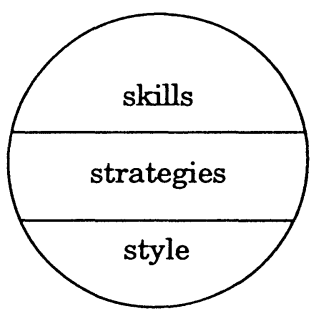

Faculty 
concerned corresponded closely to those characteristics usually associated with skills of effective teachers (Chickering \& Gamsen, 1987; Frederick, 1981; Hamachek, 1969).

\section{A Values-Based Model}

While the problem-based model seems logical and efficient-after all, faculty developers believe that we begin where the learner is-faculty developers may find that the agendas which faculty describe are not as simple as they first appeared. From the initial discussion of their teaching metaphors, faculty responded to suggestions for improvement more from the perspective of their underlying values than from their original agendas as stated in their written questionnaires.

Throughout each weekly three-hour session, the research on effective teaching that was presented in the workshop was being directly filtered through the instructional values of each of the participants. The methods of facilitating the seminar, as well as the responses of the participants, changed radically as discussions of instructional values became an integral part of the class. A second model for instructional consulting began to emerge.

\section{FIGURE 2: Values-Based Model}

\section{The Process of Faculty Consulting}

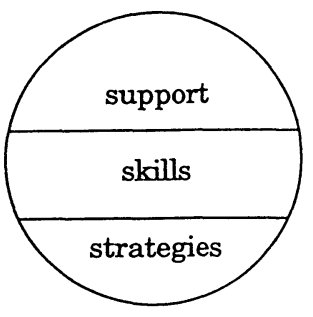

Consultant

\begin{tabular}{|c|c|}
\hline $\mathbf{M}$ & $\mathrm{P}$ \\
$\mathbf{E}$ & $\mathrm{R}$ \\
$\mathbf{T}$ & $\mathrm{O}$ \\
$\mathbf{A}$ & $\mathrm{L}$ \\
$\mathbf{P}$ & $\mathrm{M}$ \\
$\mathbf{H}$ & $\mathrm{A}$ \\
$\mathbf{O}$ & $\mathrm{G}$ \\
$\mathbf{R}$ & $\mathrm{E}$ \\
$\mathbf{S}$ & $\mathrm{N}$ \\
$\mathrm{D}$ \\
$\mathrm{A}$
\end{tabular}

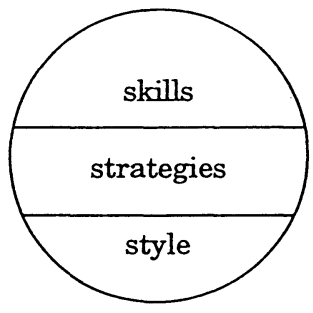

Faculty 
Figure 2 shows a values-based model of faculty consultation. As in the problem-based model, the process begins with a faculty member and a faculty consultant, both possessing skills and strategies. The faculty member brings a problem or agenda for which the consultant offers support. In the values-based model, there is a filter of values or instructional metaphors, which will be explored by the faculty and the faculty consultant in order to better understand what is needed for instructional improvement. In this filter are the metaphors of both the faculty member and the faculty consultant. As the two parties consider the faculty's problem through the filter of their metaphors, receptivity to suggestions and openness to change are more likely to develop.

\section{Outcomes of Using the Values-Based Model}

Table 1 shows three professors' initial description of class agendas, their style of teaching, their metaphors, and changes in attitudes or behaviors which occurred as the class progressed. It illustrates the contrast between the problem or class goal, as originally stated in the questionnaires, and their metaphors.

Table 1 depicts relationships between the problems which the teachers identified and their style of teaching. The metaphors seemed to provide a more abstract way of exploring the problems. During the last class session Professor A commented, "I have reluctantly decided that if I want students to be excited about chemistry, I have to make a greater effort to make the students feel comfortable at the beginning of their journey."

\section{Better Understanding of Faculty Reactions}

\section{to Seminar Content}

Knowing the faculty's values resulted in a better understanding of their reactions to new materials or ideas. For example, Professor A, in describing the values underlying his metaphors, talked at length about his fascination for his discipline. He remembered being thrilled when he began to understand abstract relationships and to get beyond simple formulas and rote memory into problem solving. Professor $\mathrm{A}$ had been an abstract thinker when he entered college, and he, like many faculty in the group, believed that abstract thinking ability should be a college 
TABLE 1

\section{Examining the Stated Agendas, the Metaphors, and the Teaching Outcomes}

\begin{tabular}{|c|c|c|c|}
\hline $\begin{array}{l}\text { PROBLEM } \\
\text { STATEMENT }\end{array}$ & EACHING & ET & $\mathbf{S}$ \\
\hline $\begin{array}{l}\text { PROF. A. CHEMISTRY } \\
\text { I think we need to discuss } \\
\text { course integrity vs. happy } \\
\text { students. I'm being forced } \\
\text { to compromise my } \\
\text { standards just to get } \\
\text { decent evaluations. In the } \\
\text { long haul this emphasis on } \\
\text { student satisfaction will not } \\
\text { be in anyone's best } \\
\text { interest. I work hard with no } \\
\text { solid results. }\end{array}$ & $\begin{array}{l}\text { Prof. A was a very } \\
\text { traditional teacher who } \\
\text { lectured, gave homework, } \\
\text { went over homework, and } \\
\text { lectured. When students } \\
\text { did not understand, he } \\
\text { became frustrated and } \\
\text { critical, convinced that they } \\
\text { simply needed to work } \\
\text { harder. He was hesitant to } \\
\text { try new ideas, but } \\
\text { discouraged about student } \\
\text { responses. }\end{array}$ & $\begin{array}{l}\text { Prof. A's metaphor was of } \\
\text { a teacher as a travel } \\
\text { guide-opening students' } \\
\text { minds to the excitement of } \\
\text { a new land with new } \\
\text { symbols, and new ways of } \\
\text { viewing things. He } \\
\text { envisioned students } \\
\text { growing to love the new } \\
\text { land and becoming } \\
\text { comfortable with the } \\
\text { changes it represented. }\end{array}$ & $\begin{array}{l}\text { became more aware of his } \\
\text { desire for students to like } \\
\text { his subject enough to do } \\
\text { the work. He began to } \\
\text { understand the need to } \\
\text { begin at the students' level } \\
\text { of knowledge and work to } \\
\text { more actvanced } \\
\text { levels.Microteaching efforts } \\
\text { showed enthusiasm and } \\
\text { less dictatorial behavior. }\end{array}$ \\
\hline $\begin{array}{l}\text { PROF. B. ACCOUNTING } \\
\text { I'm new to teaching and } \\
\text { want to learn better ways } \\
\text { to teach. I want to get } \\
\text { students to solve problems } \\
\text { coperatively instead of } \\
\text { competing. They'll need to } \\
\text { leam to work in groups. } \\
\text { Cooperative learning might } \\
\text { be what I want to learn, but } \\
\text { I'm not sure what it is. }\end{array}$ & $\begin{array}{l}\text { Prof. B was popular with } \\
\text { his students. He was } \\
\text { excited about teaching and } \\
\text { eager to learn new ideas. } \\
\text { He was known to be a hard } \\
\text { taskmaster who gave fair, } \\
\text { but difficult tests. He } \\
\text { wanted to get students } \\
\text { more involved in learning. }\end{array}$ & $\begin{array}{l}\text { Professor B drew small } \\
\text { doors opening into larger } \\
\text { doors, opening into still } \\
\text { larger doors, into an even } \\
\text { larger world. The professor } \\
\text { opened one door at a time, } \\
\text { helping students decide } \\
\text { when to open another } \\
\text { door, supporting their } \\
\text { decisions. }\end{array}$ & $\begin{array}{l}\text { as like a sponge, } \\
\text { information and } \\
\text { nmediately with } \\
\text { nts. Cooperative } \\
\text { ed to a new } \\
\text { of heads } \\
\text { with an illuminated } \\
\text { of insight." He } \\
\text { several new } \\
\text { activities for his }\end{array}$ \\
\hline $\begin{array}{l}\text { PROF. C., EDUCATION } \\
\text { With all of the new } \\
\text { certification requirements, it } \\
\text { gets worse every year that } \\
\text { I teach. I just can't fit in } \\
\text { everything they need to } \\
\text { know. I can't get the } \\
\text { students involved. They } \\
\text { need to know more when } \\
\text { they go out to teach. I can't } \\
\text { cover it all! I feel behind } \\
\text { trom the first day of class. }\end{array}$ & $\begin{array}{l}\text { Prof. C was very intense in } \\
\text { her lectures. She tried to } \\
\text { tell students everything } \\
\text { they needed to know. She } \\
\text { cut discussions short in the } \\
\text { need to cover more } \\
\text { content. She was upset } \\
\text { when her student teachers } \\
\text { had problems in teaching. } \\
\text { Her answer to almost any } \\
\text { student question was to } \\
\text { provide more information. }\end{array}$ & $\begin{array}{l}\text { Prof. C drew a stick figure } \\
\text { teacher, connected with } \\
\text { ribbon-like threads to many } \\
\text { slightly smaller stick } \\
\text { figures. Those stick figures } \\
\text { held ribbons in one hand to } \\
\text { the teacher and reached } \\
\text { out with the ribbons to still } \\
\text { smaller stick figures. She } \\
\text { said she was building links } \\
\text { from her students to their } \\
\text { students. }\end{array}$ & $\begin{array}{l}\text { Using her metaphor, Prof. } \\
\text { C was asked to describe } \\
\text { what she wanted the } \\
\text { middle link in the chain to } \\
\text { do that they don't do; she } \\
\text { discussed the need to } \\
\text { problem solve, to respond } \\
\text { on-their-feet; she designed } \\
\text { activities based on hypo- } \\
\text { thetical student problems, } \\
\text { requiring students to use } \\
\text { materials from their text to } \\
\text { support their suggested } \\
\text { responses. }\end{array}$ \\
\hline
\end{tabular}


entrance requirement. Discussions of Perry's (1970) description of the dualistic nature of the thinking of younger college students were stimulating. Instead of getting bogged down in discussions of what college freshmen should be like, faculty were more willing to consider which aspects of their disciplines could provide good examples of different levels of reasoning that might help their younger students advance cognitively. Returning to his metaphor, Professor A acknowledged that not all travelers would be equally ready to travel in a new land and that some would require more assistance than others to feel comfortable in their travels.

\section{Faculty Refer to Values in Giving Feedback}

Faculty also talked with other faculty in relation to values. Each faculty member was asked to do two microteaching sessions. Additionally, each individual brought a 10-minute taped excerpt of an actual class. It was not unusual for faculty to be unduly critical of their own teaching. In her microteaching segment, Professor $\mathrm{C}$ was very critical of her lecture, maintaining that it covered too little material. Although the faculty suggested that they had needed more time to absorb what she was teaching and to take notes, Professor $C$ did not seem to hear them. Finally, one faculty commented, "You talked about forming links from you, to your students, to their students. How will covering more material help you build the links you talked about?" Most faculty have concerns about "covering the material" vs. "teaching the students," but as Professor C struggled to answer the question, the focus shifted from looking at what the teacher was doing to discussing what the students were learning.

\section{Faculty View New Strategies as Values-Based}

Professor B, with his stated agenda of wanting to learn new ways to teach cooperation and his metaphor of assisting students to open larger and larger doors to the world, is actually representative of several of the faculty whose goals for the class were related to their ideals of teaching. Professor B was open to new and different ways of teaching, particularly to those which emphasized cooperative problem solving; thus, the instructional task with Professor B felt more straight- 
forward, more initially similar to the problem-based model. On the other hand, as he reviewed and applied cooperative learning strategies, Professor B's discipline of accounting still provided a filter which needed to be understood. He frequently raised questions concerning how group strategies worked when the problem solutions were quantitative and required precise answers, rather than creative thinking. In this case, the values filter was provided by the individual and by the nature of his discipline. In recognizing the needs of his discipline, it was possible for him to design appropriate kinds of cooperative learning experiences.

\section{Integrating Metaphors Into the Values-Clarification Paradigm}

In thinking about the role that understanding values can play in faculty consulting, it is helpful to examine the steps of values clarification as identified by Simon, Kirschenbaum, and Howe (1972). It certainly is not the role of faculty consultants to try to change faculty values to be more similar to their own. It may be helpful, though, to encourage faculty to be aware of their own values and to relate those to their teaching behaviors. Instructional metaphors can be a vehicle for that process. Applying Simon, Kirschenbaum, and Howe's paradigm for values clarification to teaching metaphors, the steps might be as follows:

Step 1: Create faculty awareness of their metaphors and assumptions about effective teaching. Simply asking faculty to draw their metaphors of teaching and share those with others encourages them to display pride and satisfaction with their images and have an increased awareness of the values that their metaphors represent.

Step 2: Encourage faculty to expand their metaphors. In sessions which followed the initial metaphor activity, faculty referred back to their metaphors, adding and/or revising them based on discussions and learning activities.

Step 3: Assist faculty in examining the values content of their teaching behaviors. Microteaching procedures provided faculty an op- 
portunity to explore consistency between their stated values and their teaching behaviors. As described earlier, other faculty encouraged Professor $\mathrm{C}$ to examine her teaching behaviors in relation to her metaphor. By engaging in the simple process of drawing a metaphor before microteaching, faculty recognized the possibility of dissonance between their values and their actual teaching behaviors.

Step 4: Introduce new metaphors and models of teaching. It is not unusual for faculty to teach as they were taught, particularly in relation to their chosen discipline. As new strategies are introduced in workshops and seminars, it is natural to explain the purpose of each strategy. Referring to the values which underlie the strategy or asking faculty to relate the new approach to a metaphor or value might develop faculty awareness of their opportunities for choice.

Step 5: Assist faculty in integrating new metaphors with their original ones. In the final workshop session, faculty used their own ideas - as well as feedback from other faculty - to develop a self-portrait of themselves as teachers. In the process of describing themselves, most referred back to their metaphors and suggested ways they had changed or added to their original image.

Step 6: Encourage written commitments to significant values. Values commitment is a culminating step in Simon's paradigm. In the seminar, teaching portfolios were introduced as a way of representing their beliefs and efforts as teachers. As a group, the workshop participants discussed the possibility of including their metaphors of teaching in their teaching portfolios.

\section{Conclusion}

Metaphors of teaching represent one simple way to encourage faculty to explore and commit to a set of instructional values. Values become the filter through which faculty relate to the skills and strategies which faculty consultants introduce. What is important for faculty developers is to realize that by assisting faculty to become aware of their assumptions about what matters in teaching, the developers are 
actually increasing the potency of their efforts to increase teaching effectiveness.

\section{References}

Chickering, W., \& Gamson, Z. (1987). Seven principles for good practice in undergraduate education [special insert]. The Wingspread Journal, $9(2)$.

Evans, L., \& Chauvin, S. (1993). Faculty developers as change facilitators: The concernsbased adoption model. To Improve the Academy, 12, 165-178.

Frederick, P. (1981). The dreaded discussion: Ten ways to start. Improving College and University Teaching, 29(3), 109-114.

Hamachek, D. (1969). Characteristics of good teachers and implications for teacher educators. Phi Delta Kappan, 50(6), 341-345.

Holt, J. (1969). The values we teach in school. Good Teaching, 87(1), 72-80.

Kerwin, M. (1987). Teaching behaviors faculty want to develop. Journal of Staff, Program, and Organizational Development,5(2), 69-72.

Perry, W. G. (1970). Forms of intellectual and ethical development in the college years: A scheme. New York: Holt, Rinehart, and Winston.

Raths, L., Harmin, M., \& Simon, S. (1966). Values and teaching: Working with values in the classroom. Columbus, Ohio: Merrill.

Rokeach, M. (1968). Beliefs, attitudes, and values: $A$ theory of organization and change. San Francisco: Jossey-Bass.

Shackelford, R. (1993). Teaching the technology of teaching: A faculty development program for faculty. To Improve the Academy, 12, 189-206.

Simon, S., Kirschenbaum, H. \& Howe, L. (1972). Values clarification: A handbook of practical strategies for teachers and students. New York: Hart. 


\section{APPENDIX A \\ How Do You Rate Your Teaching Skills?}

School: __ Arts \& Sciences; __Business; __ Music; __ Nursing;

Years of Teaching Experience: 1 to 3 ; 4 to 6 ; 7 to 10 ; 11 or more;

The skills below are often associated with teaching effectiveness. For each skill area, rate yourself according to the following scale:

- Mark $\mathbf{4}$ if you feel very satisfied with your competence in this skill area.

- Mark 3 if you feel satisfied with your competence in this skill area.

- Mark 2 if you feel dissatisfied with your competence in this skill area.

- Mark 1 if you feel very dissatisfied with your competence in this skill area.

- Mark $\mathbf{N}$ if you feel uninterested because particular skill area is not one which you usually use in your teaching or because it is a skill which does not seem appropriate to your field.

1. KNOWLEDGE OF SUBJECT MATTER (how comfortable are you with your knowledge of the material you teach? how up-to-date?)

2. ABILITY TO COMMUNICATE WITH STUDENTS (how skilled are you at giving and receiving information? how well do you adapt your material to student levels?)

3. GLOBAL PLANNING SKILLS: (how satisfied are you with your syllabus? your overall course content? your ability to set and meet long term goals?)

4. LECTURING SKILLS (how satisfied are you with your ability to promote student learning through the use of lecture?) 
5. SMALL GROUP TEACHING (how satisfied are you with your efforts to use small group methods to promote student learning?)

6. INDIVIDUAL LESSONS OR TUTORING (how satisfied are you with your ability to conduct one-on-one instruction with students?)

7. LABORATORY WORK (how satisfied are you with your ability to promote student learning through laboratory or clinical experiences?)

8. USING A VARIETY OF LEARNING ACTIVITIES (how satisfied are you that your classes incorporate a variety of learning activities appropriate to student interests, learning styles, and ability levels?)

9. INCORPORATING INNOVATIVE TEACHING STRATEGIES (How satisfied are you with your efforts to use new and innovative teaching strategies?)

10. MOTIVATIONAL SKILLS (how satisfied are you with your ability to stimulate student interest and motivation to learn?)

11. EVALUATION AND TESTING (how confident do you feel that your exams/projects/assignments actually assess student learning?)

12. ESTABLISHING RAPPORT WITH STUDENTS (do students trust/sense your concern for their learning?)

13. PROVIDING FOR INDIVIDUAL DIFFERENCES (How skillful are you at tailoring your teaching to the needs of the individuals in your classes? Are you satisfied that you create a warm climate for minority students?)

14. OVERALL TEACHING EFFECTIVENESS (how satisfied are you with your teaching skills?) 